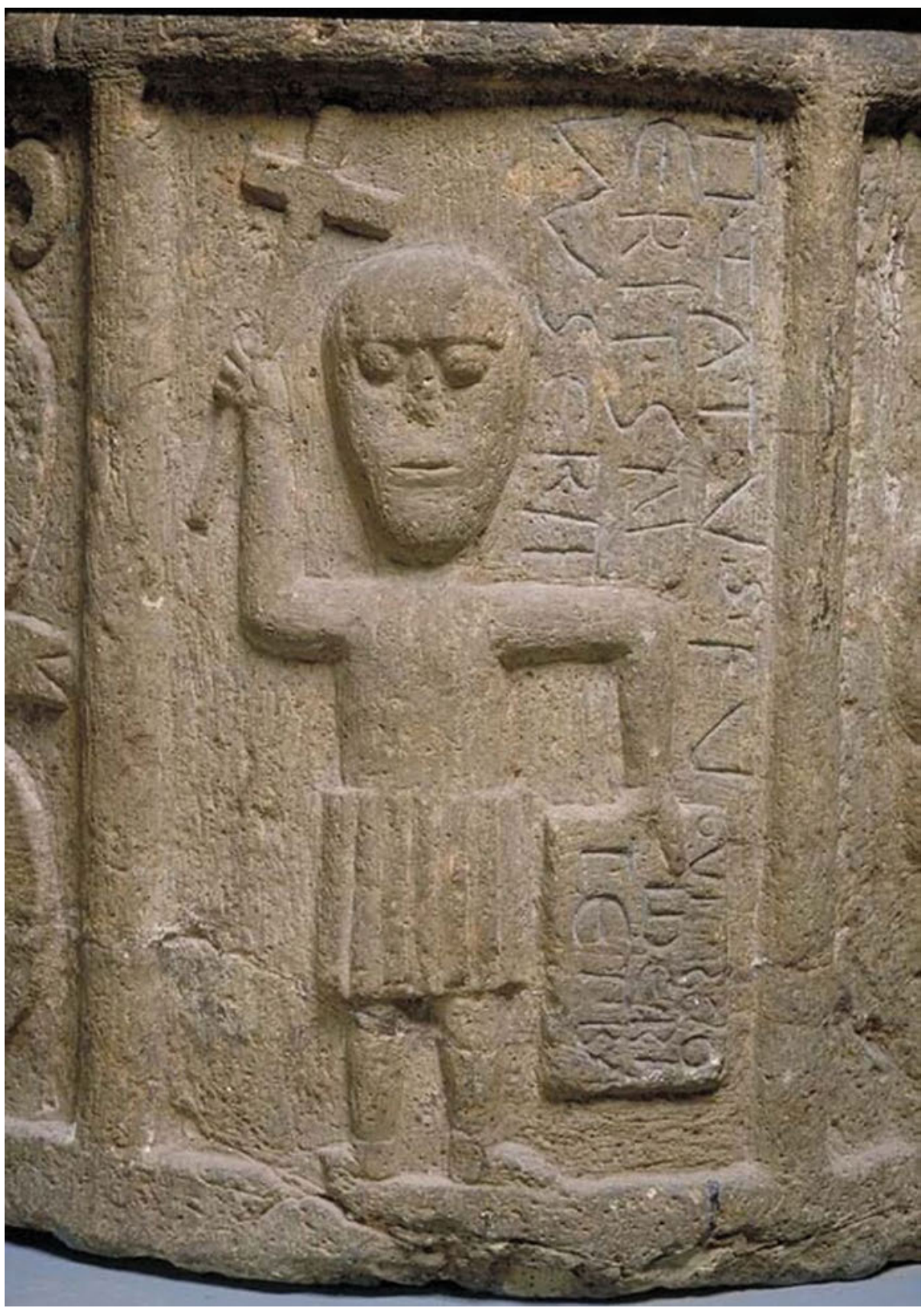

Fig. 16.1: Resurrected Christ on the baptismal font of the Ottravad Church, twelfth century.

Ә Open Access. ( 2021 Kersti Markus, published by De Gruyter. (@) BY-NC-ND This work is licensed under the Creative Commons Attribution-NonCommercial-NoDerivatives 4.0 International License.

https://doi.org/10.1515/9783110639438-017 
Kersti Markus

\section{Chapter 16 \\ The Holy City in the Wilderness: Interpreting the Round Churches in Västergötland, Sweden}

Traditions of pre-Christian society persisted longer in Sweden than in any other Scandinavian country. This chapter explores how the idea of Jerusalem may have affected changes in the rational and emotional outlook of the recently Christianized population during the twelfth century. Sweden was indeed established as a separate ecclesiastical province with the foundation of the archsee Uppsala in 1164, but the essential ideas of Christianity were slow to take root in the depths of the vast Swedish forests. In the following, light is shed on some of the strategies used by Bishop Bengt of Skara (1150-90) to change the mentality of the leaders of Västergötland by referring to Jerusalem through visual representations and modulations of the landscape.

In the twelfth century Sweden was Christianized, but still held on to the ways of old traditional society. ${ }^{1}$ The Christian imprint on the landscape consisted for the most part of wooden churches with portals and rooftops adorned with serpents, striding quadrupeds, and tendril patterns familiar from the visual world of the pre-Christian era. Even by the middle of the century, when many of the wooden churches were replaced by new churches built in stone, these images did not completely disappear. In this cultural landscape, round churches imitating the Church of the Holy Sepulchre in Jerusalem stood out conspicuously, as their form did not fit smoothly into the existing context, and their message seemed unfamiliar. An idea of the Holy City of Jerusalem might have existed at the time in the imagination of a king or a bishop, but for the majority of the population it must have remained distant and unfathomable. Inevitably, a question arises why and by whom were the round churches built?

\section{Round Churches in Scandinavia}

When all of Scandinavia is viewed from a broad perspective, we can see both regional differences and superregional similarities. The current state of research offers verified information on about thirty-four round churches, yet literature and oral tradition testify

1 See more in Tore Nyberg, Monasticism in North-Western Europe, 800-1200 (Burlington: Ashgate, 2000).

Kersti Markus, Professor of Art History, University of Tallinn, Estland 


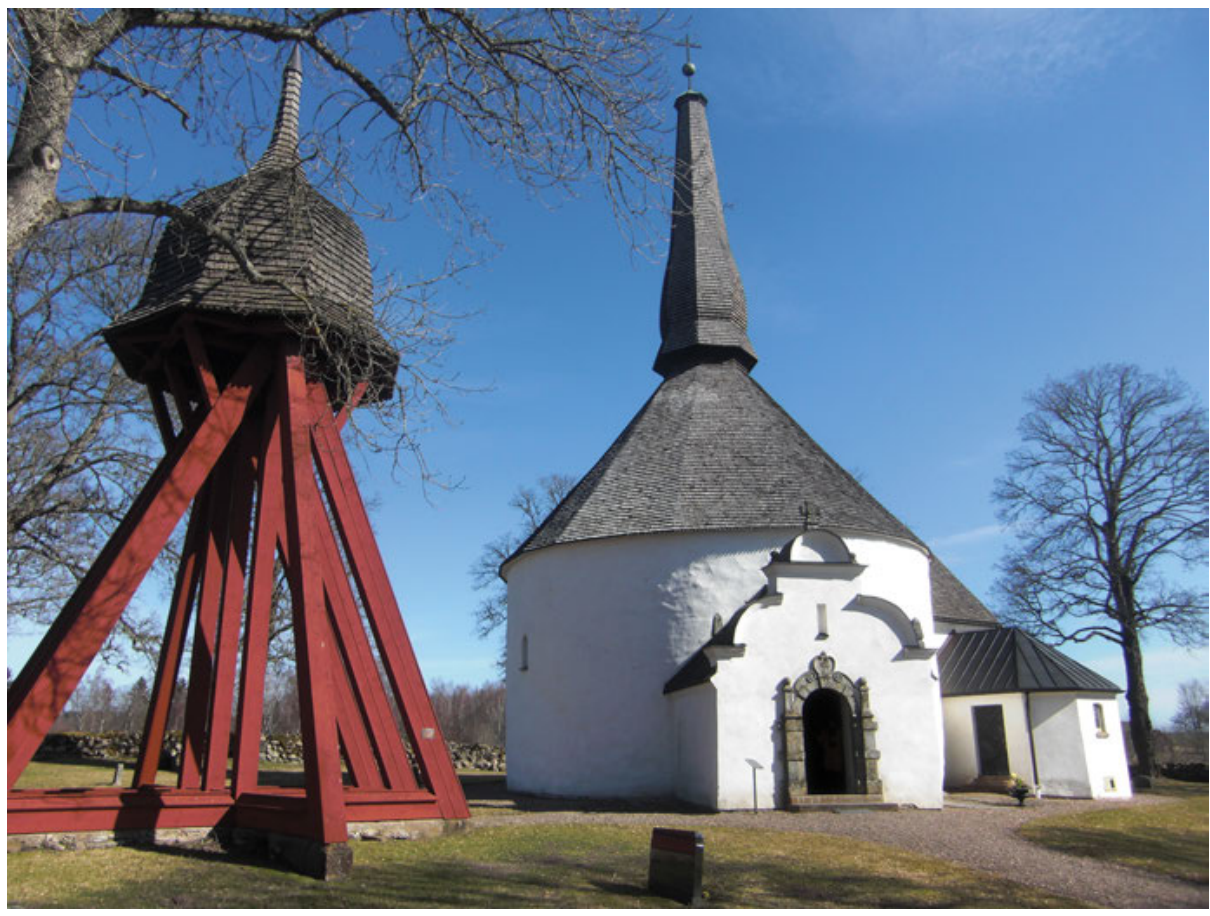

Fig. 16.2: Round church of Skörstorp.

to the existence of many more - although several of those have remained unsupported by evidence when subjected to closer study. Of the known round churches, nineteen were situated in medieval Denmark and thirteen in Sweden. In Norway there were only two, one at the Premonstratensian monastery in Tønsberg (Fig. 7.1), the other situated in the far Orkney Islands near the coast of Scotland (Fig. 6.2). ${ }^{2}$ The Danish round churches are situated either at the king's fortress (Hälsingborg, Søborg), at the king's or a nobleman's estate (Schleswig, Horne, Bjernede, Pedersborg), or at an old pagan burial complex (Himlingøje). Some of the churches have obviously been built with a consideration of local communication networks in mind, as they are situated close to a body of water that either gives access to a regional centre (Thorsager) or constitutes the main route of communication between the North Sea and the Baltic Sea (Hälsingborg). The round churches on the Isle of Bornholm form a separate group, remarkable for their positions in the landscape, well visible to everyone sailing to

2 Jes Wienberg, “Conspicuous Architecture: Medieval Round Churches in Scandinavia,” in Sacred Monuments and Practices in the Baltic Sea Region: New Visits to Old Churches, ed. Janne Harjula, et al. (Cambridge: Cambridge Scholars Publishing, 2017). 
Sweden through the Danish sounds (Ols, Nylars). They belong to Denmark's few military-purpose churches.

Differences can also be noted between the thirteen Swedish round churches. These are situated in different counties, although mostly in Götaland (Västergötland and Östergötland). Three of the churches are also found in the archipelago of Lake Mälaren, close to Stockholm. Compared to the situation around 1200, the land there has risen about 3.5 meters, so that at the time of the building of these churches, today's lake was still a cove in the Baltic Sea. Three more round churches can be found on the banks of the Kalmar Sound, where maritime traffic moved north and east of the Danish Sounds. When sailing along the coast it was possible to reach Svealand or Finland, or sail on to Livonia via the island of Gotland. ${ }^{3}$ Thus, even a brief glance at the distribution of the churches informs us about the reason why a certain location was chosen, and accordingly, a study of the round churches must include a close investigation of local circumstances. From these grounds we may proceed to more general conclusions.

The earliest comprehensive study of the Scandinavian round churches was published by Swedish art historian Hugo F. Frölén more than a century ago, ${ }^{4}$ while one of the most recent is by Jes Wienberg in 2017..$^{5}$ The subject is of broad popular interest, so that scholars often find themselves debating with amateurs seeking vindication in the media. ${ }^{6}$ In his article "Conspicuous Architecture. Medieval Round Churches in Scandinavia," Wienberg revised the current state of research and presented his ideas about the causes and presumed time-frame for the building of round churches. The earlier prevalent position that round churches functioned as defence facilities has today largely been superseded by a vision of multifunctionality: these edifices alluding to the Church of the Holy Sepulchre may have functioned simultaneously as a defence facility and even as a warehouse, with many of these churches having several floors. Moreover, Wienberg also emphasized the self-representation of the church-builders - the kings, bishops, and aristocracy - as well as the context of the Baltic crusades. ${ }^{7}$ In fact, several of the churches are situated on crusade routes: on

3 Kersti Markus, "Kuidas propageerida ristisõda visuaalselt? Taanlaste ristisõjast Eestisse 12. sajandi lõpus ja 13. sajandi algul sakraalse ehituskunsti vahendusel [How to Propagate a Crusade Visually? The Danish Crusade in Estonia in the Late 12th Century and Early 13th Century in the Light of Sacral Architecture]," Studies on Art and Architecture 24, no. 3-4 (2015).

4 Hugo F. Frölén, Nordens befästa rundkyrkor. En konst- och kulturhistorisk undersökning med 270 bilder, 2 vols., (Stockholm: Lars Frölén, 1910-1911).

5 Wienberg, "Conspicuous Architecture".

6 Thus, the Danish journalist Jan Eskildsen published a book on the Bornholm round churches, with pretensions to research: Jan Eskildsen, Bornholm og Østersøen 1060-1140. Nedslag i en historisk periode fra før den danske kirke organiserede sig, til der blev planlagt kirkebyggeri (Rønne: Bornholms Tidendes Forlag, 2014).

7 The multi-functionality of the round churches, as well as the significance of the builder's selfrepresentation in the construction of those churches, was first raised by Ing-Marie Nilsson in her 
the Isle of Bornholm, South-Eastern Scania, and on the Kalmar Sound. Earlier scholarship dates the round churches to the period of 1120-1180, but Wienberg, proceeding from coin finds and results of dendrochronology, proposes a later period for the time of their construction, even as late as the first decades of the thirteenth century. ${ }^{8}$

When considering the Danish and Swedish round churches against a wider European background, both the dates and the external form of the churches provoke questions. To start with the latter, many of the Scandinavian churches have a common feature: an apse in the form of a semicircle or three quarters of a circle in the eastern part of the round building. This feature is not characteristic of Western European churches imitating the Church of the Holy Sepulchre, but are distinctive to those of Eastern and Central Europe. ${ }^{9}$ The Church of the Holy Sepulchre built during the reign of Constantine the Great consisted of a large rotunda surrounded by an ambulatory, with the Holy Sepulchre at its centre. Eight pillars and twelve columns bore the large, open dome. There were three apses respectively in the northern, western, and southern walls, while in the East there was the atrium with Mount Golgotha. After the destruction of the church by Caliph al-Hākim in 1009, the atrium was not restored, but rather replaced with an eastern apse with a choir. This ground plan, reminiscent of a cross, was often imitated in eleventh-century Germany and France, mostly in churches built in convents or on a bishop's initiative. Nevertheless, the round churches truly flourished in the period of Western control of Jerusalem, between the first crusade in 1099 and the Saladin's conquest of Jerusalem in 1187. This period was most favourable for Western pilgrims to visit the Holy Land. ${ }^{10}$ It is evident from travellers' records that the dimensions of the Church of the Holy Sepulchre were of utmost interest to visitors to Jerusalem, resulting in pilgrims building their own churches after returning

Master's thesis defended at Lund University: Ing-Marie Nilsson, "Rundkyrkor i Norden" (Lund University, 1994), 43. For the Baltic crusades, see William Urban, The Baltic crusade (DeKalb: Northern Illinois University Press, 1975); The Livonian crusade (Washington: University Press of America, 1981); Eric Christiansen, The Northern Crusades: The Baltic and the Catholic Frontier, 1100-1525 (Minneapolis: University of Minnesota Press, 1980); Alan V. Murray, ed. Crusade and conversion on the Baltic Frontier, 1150-1500 (Aldershot: Ashgate, 2001); Iben Fonnesberg-Schmidt, The Popes and the Baltic Crusades 1147-1254 (Leiden: Brill, 2007); Alan V. Murray, ed. The Clash of Cultures on the Medieval Baltic Frontier (Burlington: Ashgate, 2009); Ane Bysted et al., eds., Jerusalem in the North: Denmark and the Baltic Crusades, 1100-1522 (Turnhout: Brepols Publishers, 2012); Torben Kjersgaard Nielsen and Iben Fonnesberg-Schmidt, eds., Crusading on the Edge: Ideas and Practice of Crusading in Iberia and the Baltic Region, 1100-1500 (Turnhout: Brepols, 2016).

8 Wienberg, "Conspicuous Architecture".

9 Teresa Rodzińska-Chorąży, Zespoly rezydencjonalne i kościoly centralne na ziemiach polskich do połowy wieku XII (Cracow: Wydawnictwo Uniwersytetu Jagiellońskiego, 2009); Anežka MerhautováLivorová, Einfache mitteleuropäische Rundkirchen. Ihr Ursprung, Zweck und ihre Bedeutung (Praha: Academia, 1970).

10 Matthias Untermann, Der Zentralbau im Mittelalter. Form - Funktion - Verbreitung (Darmstadt: Wissenschaftliche Buchgesellschaft, 1989), 52-4. See also Chapter 11 (Denys Pringle), 198-217. 
home. ${ }^{11}$ Their intentions may have varied, but offering a substitute for those unable to make a pilgrimage to Jerusalem is seen as one of the common factors. Yet, in the twelfth century the cross-shaped form was no longer topical. It tended to be replaced with a round ground plan surrounded by an ambulatory, or an octagon with a long chancel terminating in an apse in the east wall. ${ }^{12}$ After the crusaders' loss of Jerusalem, the imitation of the Church of the Holy Sepulchre lost its actuality in the West. The number of new round churches was limited, known to be built on the initiative either of the participants of the abortive Fourth Crusade (Vera Cruz in Segovia, consecrated in 1208) or of the Knights Templar (Tomar c. 1200). ${ }^{13}$ Thus, both the form and the presumably late period of construction of the round churches in East Scandinavia are at variance with the mainstream construction of round churches in Europe. Following Jes Wienberg, we may relate the erection of round churches in Scandinavia to the Baltic rather than to the Levantine crusades, and the question arises: why were round churches built even in regions far from the crusade routes?

For whom were the churches intended? Was their purpose to enhance the selfrepresentation of the church-building elites, hinting at their expeditions to Jerusalem or the Baltic, or did they have another function in the society of their time? The natural environment and the cultural landscape may prove to be the key factors in opening up the wider context of the construction of round churches. In the following, I shall consider the construction of round churches in one of Sweden's counties Västergötland which, owing to its geographical location, cannot possibly have any direct connections to the Baltic crusades.

\section{Round Churches in Västergötland}

Västergötland is the earliest Christianized region in Sweden. According to Adam of Bremen, Olof Skötkonung (c.980-1022), the first Christian king of Sweden, established the centre of the diocese in Skara in the early eleventh century. ${ }^{14}$ Skara was surrounded by Västergötland's best agricultural land, as well as the large sand- and limestone plateau of Billingen, where high-quality building material could be obtained. The highest concentration of early Romanesque churches can in fact be found on that very plateau. Another district rich in early churches is to be found north of Skara at Lake Vänern, connecting the region to Svealand and Norway. Architecturally, these single-nave

\footnotetext{
11 Colin Morris, The Sepulchre of Christ and the Medieval West (Oxford: Oxford University Press, 2005), 204.

12 The octagon erected around St Olav's shrine in Nidaros (Trondheim) is a prominent example. See Chapter 14 (Øystein Ekroll), 294-6.

13 Untermann 1989, Der Zentralbau im Mittelalter: 52, 71-76.

14 Adam of Bremen, The History of the Archbishops of Hamburg-Bremen, trans. Francis Joseph Tschan, New York: Columbia University Press, 1959.
} 


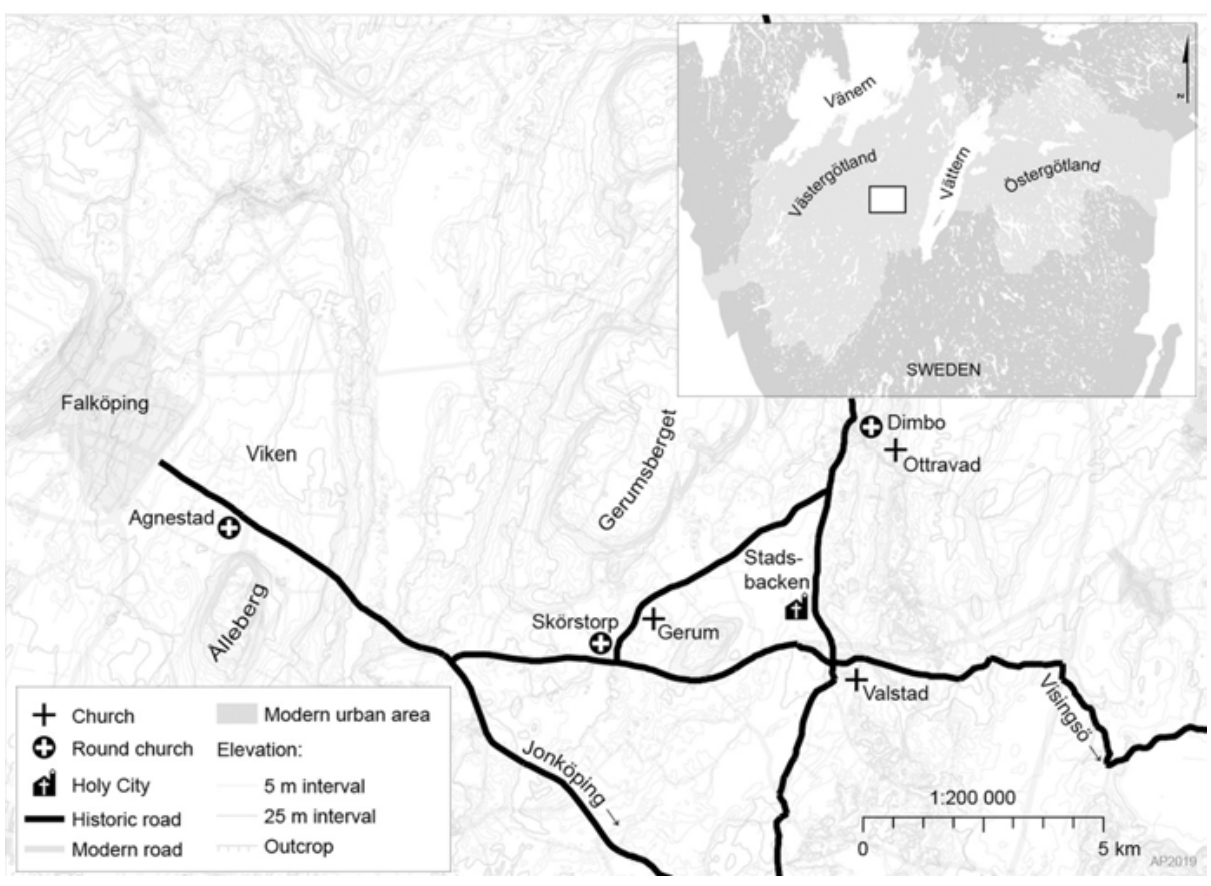

Fig. 16.3: Round churches and the place called the Holy City in the area between Falköping and Lake Vättern in Västergötland.

churches can be divided into two categories: having either a narrower rectangular chancel or a chancel with an apse. Most were built from the second half of the twelfth to the early thirteenth century. The towers are few, and secondary - all of them were erected in the thirteenth century. The rare exceptions are the Skara Cathedral and the Husaby Church. Husaby, originally a royal estate, was acquired by the bishop in the twelfth century (King Olof was baptized here). ${ }^{15}$ Thus, it can be said that in the midtwelfth century, stone churches were still rare in Västergötland. ${ }^{16}$

The round churches of Västergötland can be found south of Skara, near the old trading centre of Falköping. This was the meeting point of several important roads. In the Middle Ages, one of the most important equestrian roads connecting Sweden to Denmark was Ätrastigen, starting from the Danish Halland and proceeding to

15 The towers of Skara Cathedral and Husaby Church may have been erected in the late twelfth or early thirteenth century. Skara Cathedral was probably a basilica. Markus Dahlberg, Skaratraktens kyrkor under äldre medeltid, Skrifter från Skaraborgs länsmuseum (Skara: Skaraborgs länsmuseum, 1998), 94-6, 131-2.

16 Dendrochronologically, the churches of Götene, Skälvum, Forshem, Marum, and Skalunda have been dated to the first half of the twelfth century. Dahlberg 1998, Skaratraktens kyrkor: 86-7. 
Svealand over Varnhem. Another road led from Småland's trading centre Jönköping towards Skara via Falköping.

The ruins of Agnestad round church lie a few kilometres east of Falköping, close to the Alleberga plateau, which has been called a holy mountain (Fig. 16.3). One of Sweden's most prominent archaeological finds was discovered here - a golden collar from the fifthsixth century [Ållebergskragen]. To the north of the church there is a settlement site called Viken, which seems to indicate proximity to a body of water (vik is the modern Swedish word for a bay or gulf), although there has never

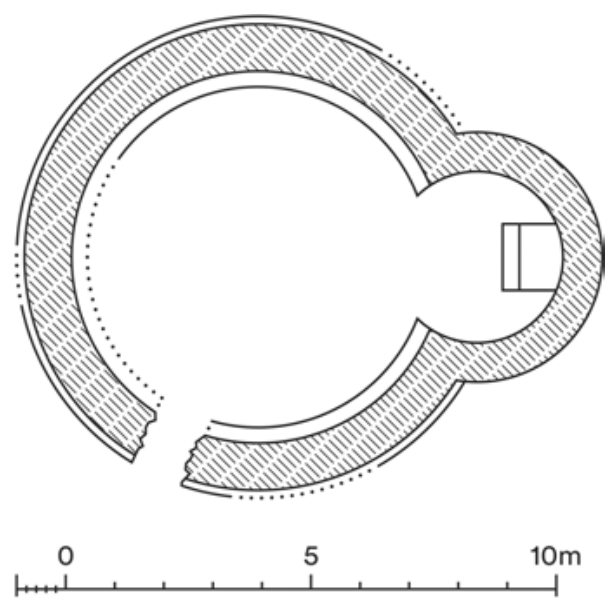

Fig. 16.4: Round church of Agnestad. After Frölén 1910: 106. been one in that particular location. According to the archaeologist Lars Bägerfeldt, the name is derived from the same origin as the English world wik, meaning an assembly point. While Svealand had to provide a fleet to serve the King, the Västgöta men were to contribute cavalry, and one of the assembly points for the cavalry could have been on that spot. This would explain why the English Bishop Sigfrid, who had baptized King Olof, chose to consecrate the site of Agnestad church, ${ }^{17}$ and why the round church was later erected there. The church, in ruins today, consisted of a circular building (with an inner diameter 8.6 meters) and a small apse (Fig. 16.4). No remains of columns have been found, and we may therefore assume that the church had a wooden roof. A round stone bench follows the inner perimeter of the church wall. ${ }^{18}$

From Agnestad church, the road proceeded to Falköping and further to Lake Vättern, whence Östergötland could be reached via the island of Visingsö. In the twelfth century, Visingsö was an important administrative and political centre, playing a central role in the transport of iron from Jönköping to the regions of Östergötland and Mälardalen (the valley of Lake Mälaren). ${ }^{19}$ When proceeding from Agnestad towards Visingsö, we reach the Skörstorp round church after about ten kilometres. The church has survived, but has been subject to several reconstructions throughout the centuries (Fig. 16.2). The walls of the round church building, with masonry and a foundation profile similar to those of the Agnestad church, have been preserved in their

17 Västgötalagen, ed. H.S. Collin and C.J. Schlyter, Corpus iuris Sueo-Gotorum antique. Samling af Sweriges gamla lagar, 1, Stockholm: Haeggström, 1827.

18 Frölén, Nordens befästa rundkyrkor, I, 102-7.

19 Kristina Franzén, “Kyrkan i landskapet," in Småland. Landskapets kyrkor, ed. Marian Ullén (Stockholm: Riksantikvarieämbetet, 2006), 24. 


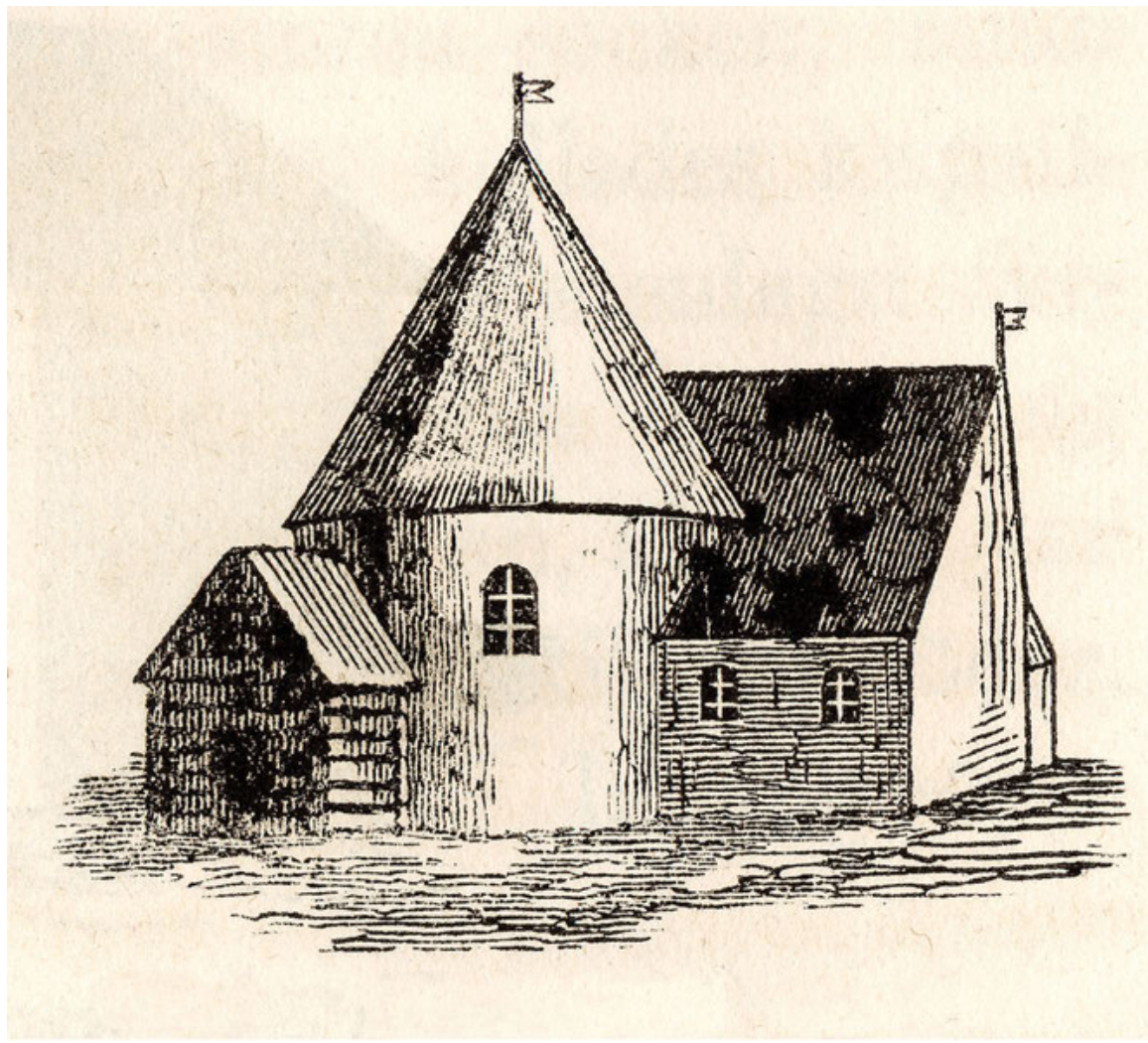

Fig. 16.5: Round church of Dimbo. After Hyltén-Cavallius 1864: 202.

original shape. Yet, the inner diameter of the Skörstorp church is longer - 10.2 meters. Columns have also not been found here during excavations, ${ }^{20}$ so it may be assumed that this church, too, had a wooden roof. There is no information whatsoever about the appearance of the earliest eastern part of the church.

At Skörstorp, the road splits - one route proceeds to Östergötland, the other leads to the Dimbo round church situated about six kilometres to the north. Although this building no longer exists (it was used for construction material during the nineteenth century), the site and the preserved drawings give a satisfactory account of the church's past appearance and significance (Fig. 16.5). ${ }^{21}$ Just as in Skörstorp, the chancel in Dimbo was rebuilt in a later period, and its size, when compared to the round building, underpins the modest size of the original church. ${ }^{22}$ Thus, Dimbo round

20 Frölén, Nordens befästa rundkyrkor, I, 97.

21 P. E. Lindskog, Försök till en korrt beskrifning om Skara stift, Häfte III (Skara1814), 35.

22 Frölén, Nordens befästa rundkyrkor, I, 100-1. 
church seems to have been quite similar to the Agnestad church. The church was situated on top of a hill about ten meters high, on the side of the important road proceeding to the north from Jönköping. Västergötland's largest burial site, consisting of c. 260 remains, including 214 burial mounds - the largest being 16 metres in diameter and 1.5 metres high - is to be found in the neighbourhood. ${ }^{23} \mathrm{~A}$ burial site of this kind could not have been intended for local inhabitants, but must have been a collective burial site of a larger settlement area. ${ }^{24}$

When comparing the location of the three churches in the landscape, the more unusual the position of the Skörstorp church becomes. While Agnestad church is situated on a wide plain and Dimbo church upon a hill, Skörstorp church stands in a shallow depression at the beginning of a valley road between two hills. After less than two kilometres, the road takes us to the Östra Gerum church, whose churchyard was consecrated by Bishop Sigfrid. ${ }^{25}$ The location probably had an equal significance to Agnestad in pre-Christian society, and it was considered important to erect a Christian shrine here. What could have been the reason? Throughout the centuries, people have brought offerings to the Gerum church in the hope of fulfilment of their prayers. ${ }^{26}$ Near the church, there is an ancient sacrificial well, suggesting that the ecclesiastical powers attempted to channel the prestige of older pagan cult sites into the new Christian sanctuaries. This was obviously a popular, much-visited site, with good prospects to become a pilgrim route. Can it then be a coincidence that there were churches - Skörstorp and Dimbo respectively - at each end of the road?

\section{The Holy City of Bishop Bengt}

There is yet another interesting place in the area. East of Östra Gerum - about four kilometres as the crow flies - there is a hill c. 40 meters high called Stadsbacken (The City Hill), which may have been the site of the Holy City [Denn Heliga stadh] mentioned in sixteenth-century sources. ${ }^{27}$ There was a church there and fairs were held yearly at Pentecost. Although there are no traces left of the church itself, its size must have been remarkable considering the size and weight of the bell. In 1541, the bailiff Torsten Hendricson composed a list of the bells of forsaken churches in the area

23 Swedish National Heritage Board: http://www.fmis.raa.se Dimbo 6:1.

24 Johan Runer, Från hav till land eller Kristus och Odalen: en studie av Sverige under äldre medeltid med utgångspunkt från de romanska kyrkorna (Stockholm: Stockholms universitet, 2006), 328.

25 Västgötalagen 1827, 304.

26 Lindskog, Försök till en korrt beskrifning om Skara stift, 21-2.

27 See more in: Bo Lundqvist, Falköping genom tiderna. Del I. Falköpings historia. Från äldsta tid till omkring år 1620 (Falköping: Drätselkammaren, 1940), 231; Folke Högberg, "Gåtan om 'Den Heliga Staden’ i Västergötland,” Medeltidsstudier i Västergötland. Västergötlands Fornminnesförenings Tidskrift 6 (1971): 21. 


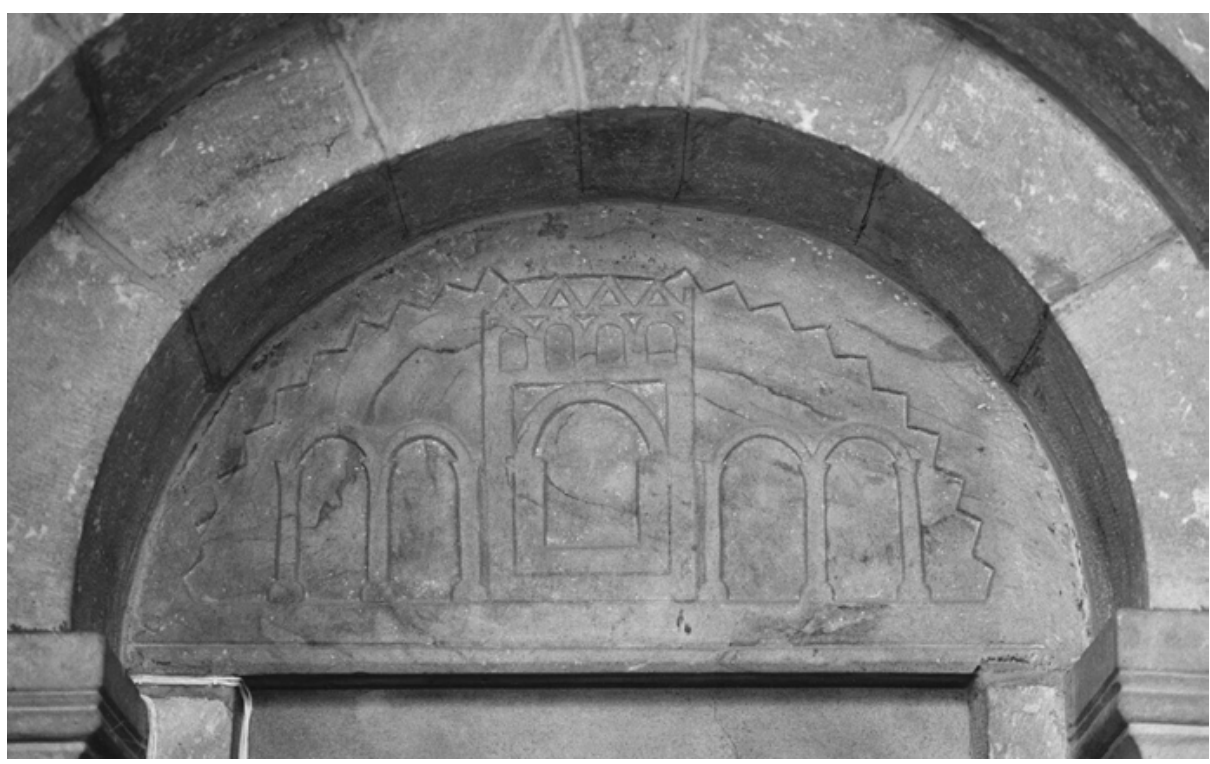

Fig. 16.6: Tympanum of the southern portal of the church of Valstad.

between Falköping and Lake Vättern: their average weight was around $200 \mathrm{~kg}$, but the bell of the Hellige stad weighed 561 kilos. $^{28}$ In the immediate vicinity of Stadsbacken there is Valstad, which - considering the local road network - must have been a regional centre. On the tympanum of the southern portal of the Romanesque church of Valstad there is a figure depicting a cross-section of a building, which according to several scholars may refer to St John's vision from the Book of Revelation: "I saw the Holy City, the New Jerusalem, coming down out of heaven from God" (Rev 21:2) (Fig. 16.6). ${ }^{29}$ As no other similar relief is known from medieval Swedish art, parallels with the Holy City situated close by seem unambiguous here.

When considering the placement of the round churches, there can be no doubt that we are looking at a deliberate and elaborate geographical composition. Bishop Bengt of Skara built the Agnestad and Dimbo churches, as has been established by the list of the bishops of Skara diocese added as an appendix to the oldest manuscript of the Elder Westrogothic law. ${ }^{30}$ In earlier historiography, Bengt's tenure is usually dated to 1150-1190, deduced from mentions of the preceding and succeeding bishops in historical sources. St Erik Jedvardsson, King of Sweden (r. 1156-1160), was

28 Högberg, “Gåtan om 'Den Heliga Staden', "21, 27.

29 Högberg, “Gåtan om 'Den Heliga Staden',” 27; Jan Svanberg, Västergötlands medeltida stenskulptur (Stockholm: Signum, 2011), 49-50.

30 Västgötalagen 1827, 306; Dahlberg, Skaratraktens kyrkor, 158. 
Bengt's uncle, who was killed at an early age (hence, his short period of reign). It is, however, not realistic to assume that they would have occupied senior positions simultaneously. It is more probable that Bengt was a contemporary of his cousin King Knut Eriksson, who ruled Sweden 1167-1195. Nevertheless, the same list of bishops mentions that Bengt built the church of Götala, whose precise site remains unknown, although local tradition connects it to a place where a round wall with a 10-meter diameter has been preserved. Moreover, in the register of the Swedish National Heritage Board, this site is recorded as the location of Götala Church. ${ }^{31}$ It is possible that it may even have been a round church. Götala was the site where the All-thing of Götaland was held, some kilometres east of Skara, ${ }^{32}$ where decisions on both warfare and taxes were made, and cult ceremonies were held, as well as festivals and games. ${ }^{33}$ The supposed church ruins lie only about 800 meters from the All-thing square.

To sum up: Agnestad Church was built for the greatest trade centre of Västergötland, where the assembly place of Västergötland's cavalry also may have been situated; while Götala Church stood close to the meeting place of all leaders, with the Dimbo church at the region's most important burial site. Hence, we may conclude that Bishop Bengt's round churches were components of a specific layout carrying a certain message to the people of Västergötland. What was that message? Swedish archaeologist Johan Runer gives one possible answer in his doctoral dissertation (defended in 2006), where he considers changes in land ownership in the last decades of the twelfth and the early thirteenth centuries. When previously important matters had been decided at Things, the old gods had been part of the human world, and the primary way of thinking had been collective. The Christian God - omnipotent and triumphant - transcended the human sphere, while his earthly powers were channelled through the offices of the Church and the divinely sanctioned right of the King. Earlier, the community authorized the kings to control the common property, but in the thirteenth century there was a change: the taxes and common land, previously owned collectively, were transferred into the sole ownership of the King and the Church. Runer dates the offset of this change to the rule of King Knut Eriksson, who promoted the sanctification of his father King Erik as part of the legitimation of the dynasty's divine right to the Swedish throne. ${ }^{34}$ Moreover, the reliquary in

31 Swedish National Heritage Board: http://www.fmis.raa.se, Skara 38:2.

32 Gösta Börjesson, Ödekyrkor i Västergötland (Skara: Skaraborgs länsmuseum, 1994), 39; Ivar Lundahl, Det medeltida Västergötland (Uppsala: A.B. Lundequistska Bokhandeln, 1961), 186-87.

33 For more about thing, see: Stefan Brink, "Legal Assemblies and Judicial Structure in Early Scandinavia," in Political Assemblies in the Earlier Middle Ages, ed. Paul S. Barnwell and Marco Mostert, Studies in the Early Middle Ages (Turnhout: Brepols, 2003); Stefan Brink, "Legal Assembly Sites in Early Scandinavia," in Assembly Places and Practices in Medieval Europe, ed. Aliki Pantos and Sarah Semple (Dublin: Four Courts Press, 2004).

34 Runer 2006, Från hav till land eller Kristus och Odalen: 335-36. For royal saints and strategies of legitimation, see also Chapters 5 and 14 (Øystein Ekroll), 86-93 and 270-98, and Chapter 24 (Björn Tjällén), 520-33. 
the family's private church at Eriksberg, 30 kilometres south-west of Skara, containing a piece of cloth from the Holy Sepulchre as well as a piece of the True Cross, fits into this context. The reliquary has been dated to the rule of Knut Eriksson, who died at the Eriksberg royal estate. ${ }^{35}$ As the Erik dynasty resided in Västergötland, Bengt's actions can be seen as the building of an earthly Jerusalem, bringing the Holy City to Västergötland, and hence, a way of achieving a symbolic visualization of the incarnate God.

\section{The New Elite Elected by God}

This interpretation of the church buildings is underpinned by the sculptural ornaments of the churches in the region. Besides the aforementioned temple relief on the south portal of Valstad Church, there is an image of the resurrected Christ on the western portal, with a cross in one hand and a stone tablet with the inscription DNS IHS XRS (Dominus Ihesus Christus) in the other. A similar image of the resurrected Christ is found on the baptismal font of Ottravad Church, although with more space for the text, so the point becomes clearer: those who believe and are baptized will find salvation (Fig. 16.1). ${ }^{36}$ The first face of the cylindrical baptismal font shows Jesus Christ on the cross, surrounded by curling tendrils (Fig. 16.7), and on the next face we can see a militant serpent in the Urnes style associated with the Viking era (Fig. 16.8). This is followed by the image of Christ holding a raised cross: Evil has been vanquished and Christ has risen from the dead. The next face depicts a man sitting on a throne in an attitude of benediction, holding a book. Although the figure lacks a halo (as does the figure of the resurrected Christ) and the gesture of benediction is made with all five fingers, he could still be assumed to represent Christ Pantocrator. On the next face, a man places a cross on a burial mound (Fig. 16.9). And finally, in proud solitude between the two ornamental tablets, we see the stone master himself. He has depicted himself in three-quarter view, carving a stone, with a dragon and a ram in the background, and a smiling lion in the foreground. This grandiose self-presentation speaks of the master's senior status (Fig. 16.10). As the handwriting of the Ottravad master can also be seen in the church of Södra Ving, another of the churches founded by Bishop Bengt, he may have been the bishop's stonemason. ${ }^{37}$ Ottravad Church was

35 Viola Hjärnfäll, Medeltida kyrkmålningar i gamla Skara stift, Skrifter från Skaraborgs länsmuseum (Skara: Skaraborgs länsmuseum, 1993), 29-42; Mereth Lindgren, "Metallskulpturen," in Signums svenska konsthistoria. Den romanske konsten, ed. Lennart Karlsson, et al. (Lund: Bokförlaget signum, 1995), 297; P. E. Lindskog, Försök till en korrt beskrifning om Skara stift, Häfte V (Skara, 1816), 376.

36 Svanberg, Västergötlands medeltida stenskulptur, 43.

37 In Jan Svanberg's opinion the work can be attributed to the King's master stonemason, as the royal estate of Ettak was situated only c.10 km from Valstad Church. Svanberg, Västergötlands medeltida stenskulptur, 52. 
less than two kilometres from Dimbo Church, and was demolished at the same time as the latter. According to descriptions, both the church and the tower were constructed from sandstone ashlar blocks, ${ }^{38}$ and may therefore have been quite similar to those of Valstad Church. The church's proximity to the region's most important burial site also speaks for the senior position of the patron.

We may assume that round churches were erected on the bishop's initiative, but this could only have taken place with the consent of the local rulers. The Skara region has been considered the centre of both ecclesiastical and regal power, and the area between Falköping and Lake Vättern was the centre of the local elite. ${ }^{39}$ The network of round churches with Helliga Staden (the Holy City) was erected in the vicinity of Falköping in order to create a sacred land-

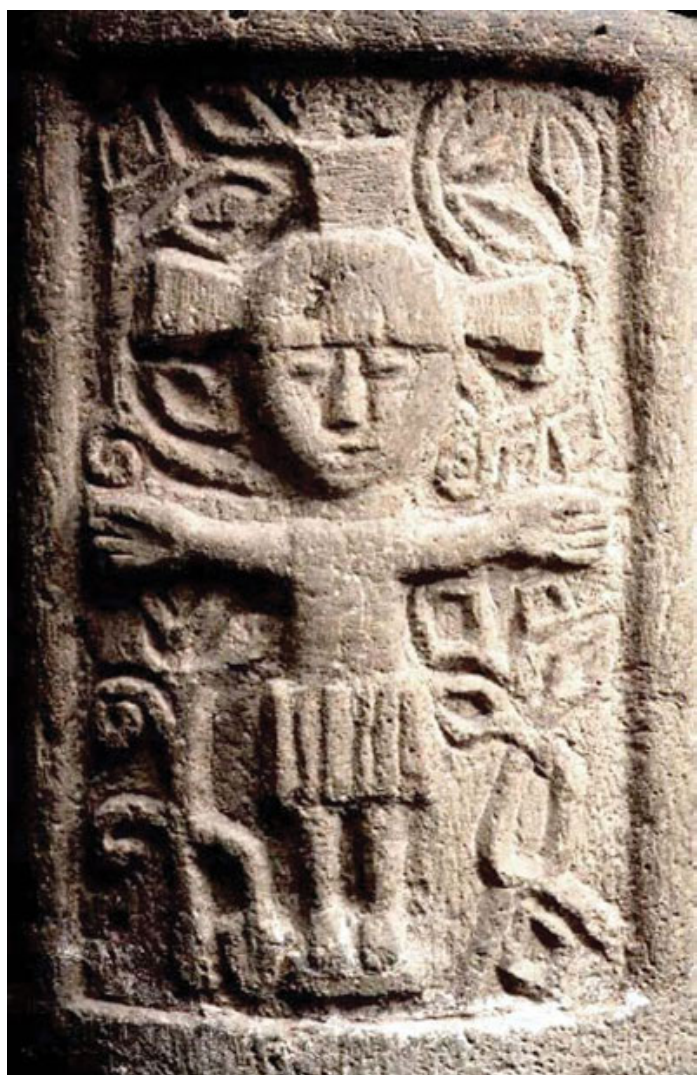

Fig. 16.7: Jesus Christ on the cross. The baptismal font of the Ottravad Church, twelfth century. scape, unique in the larger context of Scandinavia. As Skörstorp Church was not included in the list, it could not have been built by Bengt. Obviously, the bishop's initiative must have met with strong local support, yet this may have involved only a small part of the local elite. Drawing parallels with Denmark, where ecclesiastical power was very closely connected to the Hvide dynasty, ${ }^{40}$ who wished to stand out among other families as rulers by divine right, thus acquiring more power, we could assume similar ambitions for the Erik dynasty in Västergötland. Even though the first

38 Lindskog, Försök till en korrt beskrifning om Skara stift, 37.

39 Kristina Carlsson, Var går gränsen? Arkeologiska uttryck för religiösa och politiska aktörer $i$ nuvarande Västsverige under perioden 1000-1300, Lunds Studies in Historical Archaeology (Uddevalla: Bohusläns museums förlag, 2007), 152.

40 Lars Hermanson, Släkt, vänner och makt. En studie av elitens politiska kultur i 1100-talets Danmark (Gothenburg: Göteborgs universitet, 2000). 


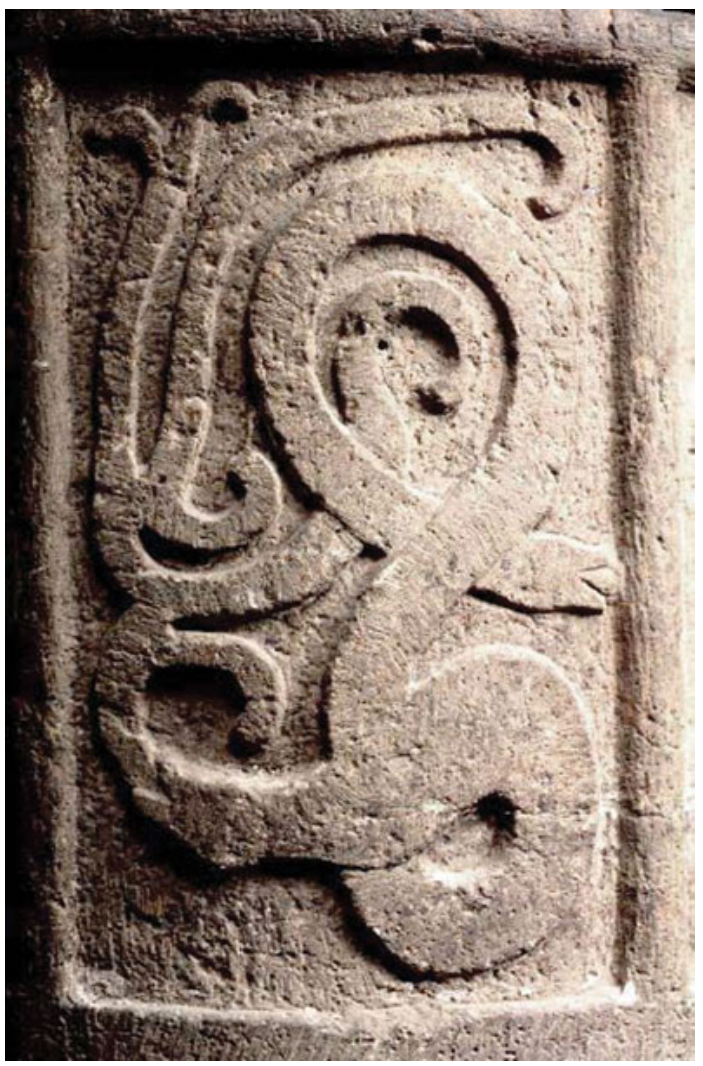

Fig. 16.8: Serpent in the Urnes style on the baptismal font of the Ottravad Church, twelfth century. churches had already been built in the region in the early eleventh century, it seems that it was during Bishop Bengt's term of office that the Christian transformation of the landscape was completed.

\section{Conclusion}

In history and art history writing, twelfth-century Scandinavia is usually labelled as the Early Middle Ages. This designation may lead us to suppose that Christianity was already deeply rooted there by that time, and the social order characteristic of medieval Christendom fully established. This interpretation may be modified, at least with respect to parts of Sweden. The use of motives from Viking art in church decorations shows that the old, familiar visual world still continued to exist. It is likely that the local mentality was still predominantly rooted in the old and traditional, and the new stone churches were an attempt to bring Christianity closer to the people by the use of familiar symbols. Therefore, the construction of round churches can be seen as a powerful step towards changing that mentality. The exterior form of the wooden churches was reminiscent of both Viking halls and ships. The first few stone churches in rural areas were remarkable for their new material, while their external form still preserved the visual resemblance to the wooden churches. The construction of western towers became significant only by the late twelfth century. Thus, the association with the death and resurrection of Christ in the form of references to the Church of the Holy Sepulchre at locations with great symbolic value to the local community (e.g. the All-Thing grounds, burial sites, assembly points) must have had an immense spiritual impact. The builders of those churches wished to ensure their position in society, demonstrating their divinely sanctioned right to rule. Nevertheless, it is very important to consider the date 


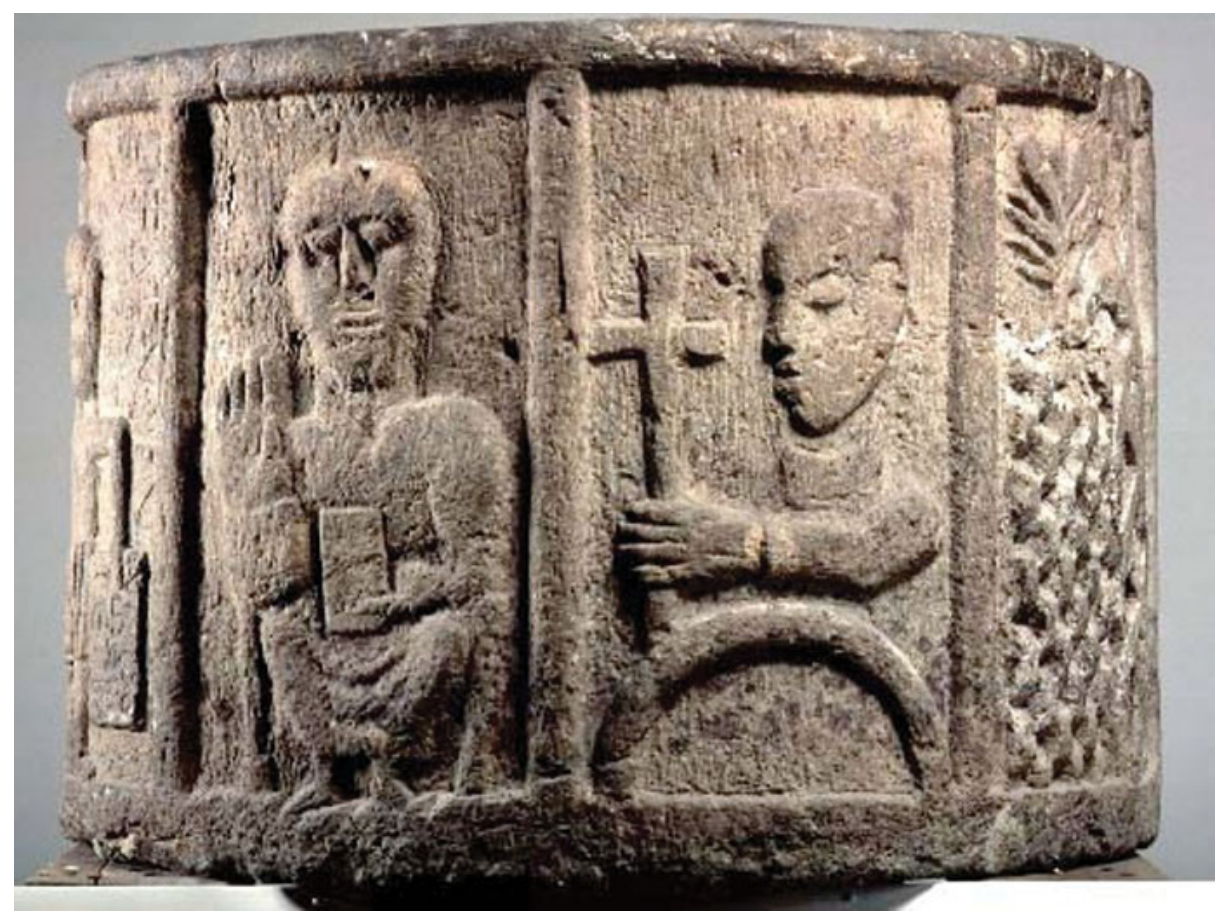

Fig. 16.9: Christ Pantocrator and a priest (?) placing a cross on a mound. The baptismal font of the Ottravad Church, twelfth century.

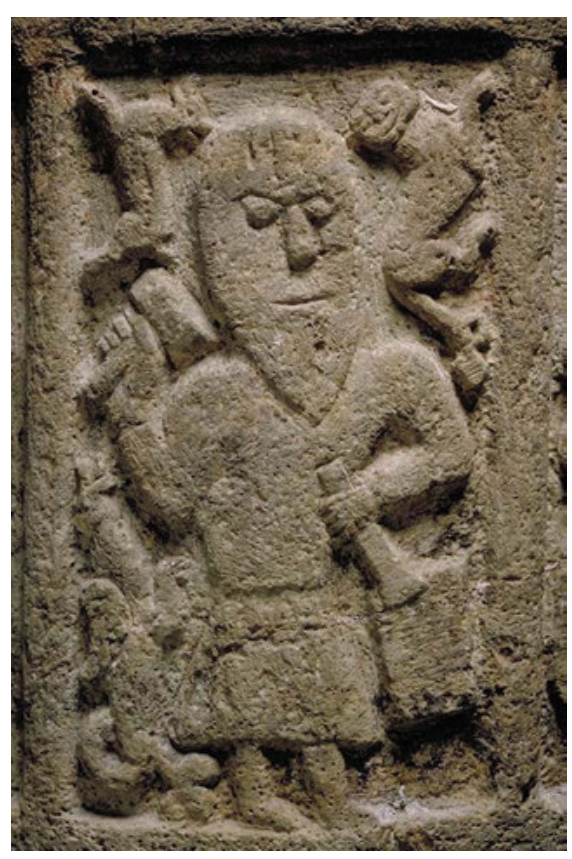

and location of each of the round churches, as the social context may have affected the content of the message. This is especially relevant for the thirteenth-century round churches, which without exception were situated at important communication routes, and can be regarded as having been built in the context of the Baltic Crusade.

Fig. 16.10: Self-presentation of the stone master on the baptismal font of the Ottravad Church, twelfth century. 